\title{
根における金属キレート物倎の分泌機能
}

\section{岡山大学資源生物科学研究所・馬 建鋒}

植物が地上部で光合成によって固定した炭素の一部は根から分泌される。分泌される有機物は糖類、 ビタミン類、アミノ酸、有機酸、酵素、ヌクレオチド、フラボノイドなど多様性に富み、植物の種類 や生育条件によって分泌する物質が異なる。これらの物質は根圈に棲息している微生物に炭素源とし て供給されるだけではなく、養分の可溶化や有害金属の解毒などに重要な役割を果たしている。ここ では、私の研究を中心に根から分泌される金属キレート物質について概説する。

1.鉄キレート物質ームギネ酸類

鉄は植物の生育にとって微量必須元素である。土滾中には鉄が平均 $3.8 \%$ 程度存在しているが、そ のほとんどが不溶性のため、植物が直接利用することはできない。しかし、一部の植物は長い進化の 過程で、不溶性の鉄を利用する機構を獲得してきた。現在その機構は戦略 I と戦略IIに分けられてい る（Römheld, 1987）。戦略 I には双子葉植物やイネ科以外の単子葉植物が含まれ、根からプロトン や有機酸、還元性物質（例えばフェノール系化合物）等を分泌することによって、不溶性鉄を可溶化 する。これに対して、戦略IIを持つ植物は根からムギネ酸類と呼ばれる三価鉄キレート物質を分泌す る。現在このような戦略を持っているのは一部のイネ科植物に限られる。

ムギネ酸は最初にオオムギの根の分泌液から単離された物質で、その構造が1978年に竹本らによっ て明らかにされた(Takemoto et al., 1978)。その後、他のイネ科植物の根分泌液から異なる構造を 示す化合物が単離され、現在計 7 種類の化合物が同定されている（そのうちの一つは今年我々によっ て同定されたばかりである）。図 1 に示すように、ムギネ酸類は六配位で鉄と結合し、鉄と高い結合 能力を有している（安定度常数18.1）。そのため、pHの高い土裹において不溶性の鉄を特異的に可 溶化することができる。

ムギネ酸類の生合成は根において行われ、鉄欠乏によって誘導される。その生合成経路は図 2 に示 すようにほぼ明らかにされている。植物の種類によって生合成されるムギネ酸類が異なるが、最初の 前駆体はすべてL-メチオニンである(Mọi and Nishizawa, 1987, Kawai et al., 1988, Ma and Nomoto, 1992, 1993, 1994a,b).このメチオニンはメチオニンサイクルという経路によって作られる

(Ma et al., 1995).また、L-メチオニンから最初に合成されるムギネ酸類である2'-デオキシムギネ 酸までの経路はすべてのイネ科植物に共通で、その後の経路は植物の種類によって異なる（図 2)。 他のムギネ酸類は2'-デオキシムギネ酸の異なる部位での水酸化によって合成されるが、その詳細に ついては原著論文を参照されたい（Ma and Nomoto, 1992, 1993, 1994a）。さらに、最近、異なる 部位の炭素の水酸化は別々の遺伝子によって支配されていることが明らかとなった(Ma et al., 1998). すなわち、炭素の 2 '位を水酸化する遺伝子はオオムギの 4 番染色体の長腕に座乗しているに対し、炭 素の 3 位を水酸化する遺伝子は 7 番染色体の長腕に座乗している。類似した機能を持つ遺伝子は異な る染色体上に座乗していることが非常に興味深い。

生合成されたムギネ酸類は不溶性の鉄を獲得するために、根外へ分泌されなければならない。ムギ ネ酸類の分泌は特徵的な日周性を示す(Takagi et al., 1984)。一般的に、日の出から2時間後から分泌 し始め、3 時間ほど続いたあと、終了する。しかし、体内では分泌終了から翌日の分泌までムギネ酸 類がずっと合成され続けている。こうして体内に蓄積されたムギネ酸類は、翌朝、集中的に短期間で 外に分泌されるのは、微生物による分解や根圈外への拡散を防ぐための植物の巧みな戦略と考えられ る。ムギネ酸類の分泌の日周性について、温度か光の変化が引き金になっているのではないかと推測 されているが、その詳細なメカニズムについては明らかにされていない。

分泌されたムギネ酸類は鉄と錯体を作ることによって、不溶性の鉄を可溶化し、最後にムギネ酸類一 鉄輸送体によって体内に運ばれる。その詳細は総説を参照されたい(Ma and Nomoto, 1996). 

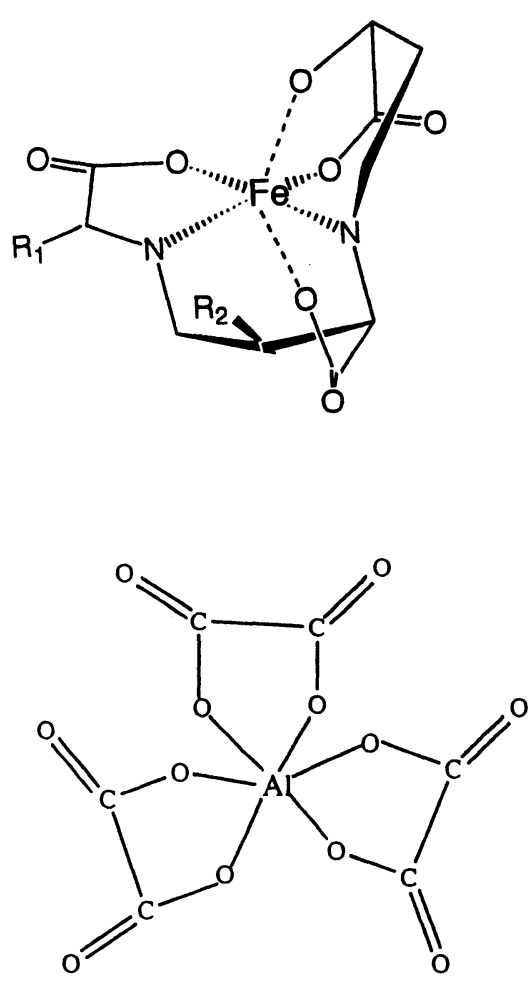

図1鉄(III)-ムギネ酸類錯体の模式図と $\mathrm{Al}$ ーシュウ酸(1:3)錯体の構造

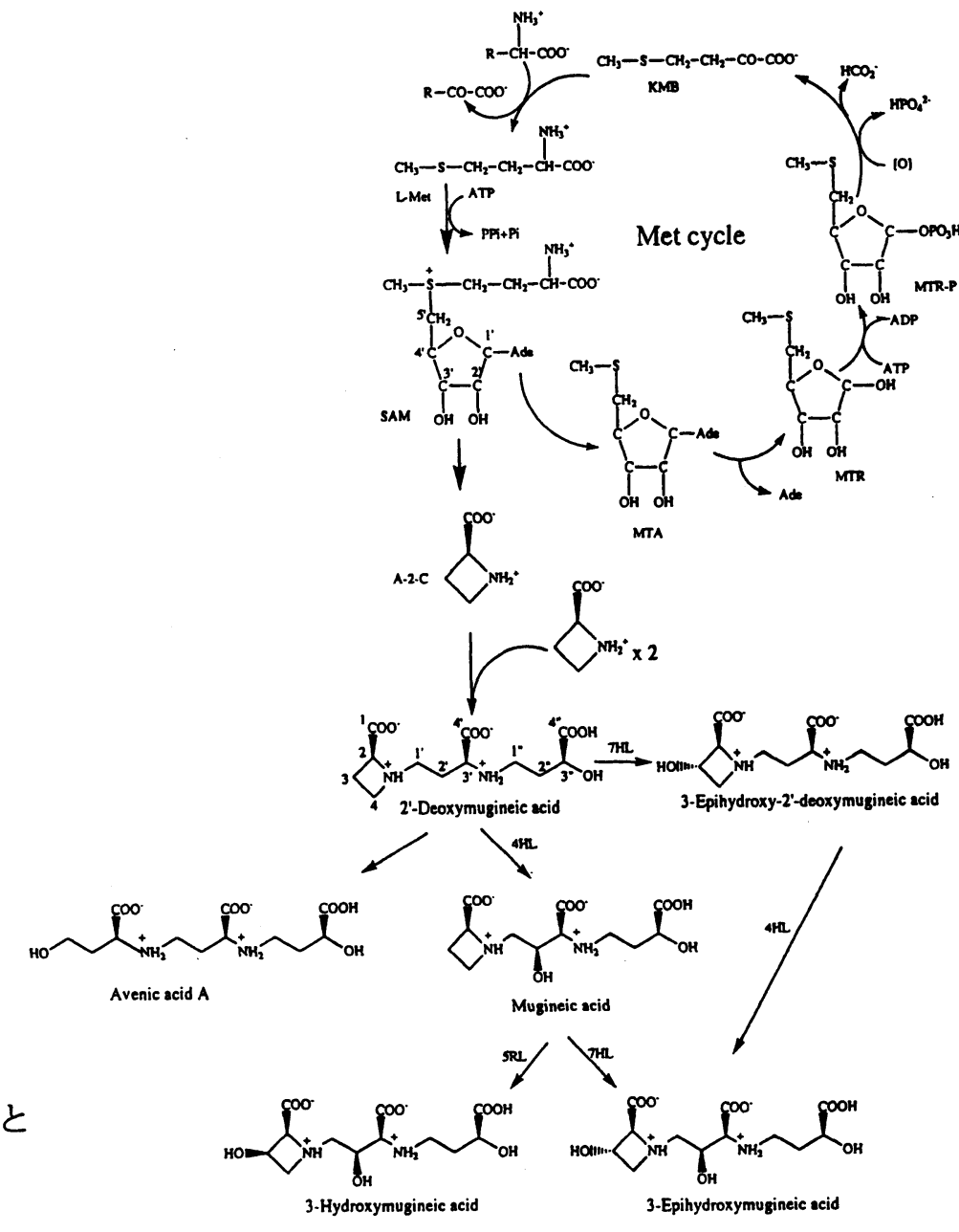

図2 ムギネ酸類の生合成経路と関与する遺伝子の座乗染色体腕

\section{2.アルミニウムキレート物質}

アルミニウムイオン毒性は酸性土壤における主な作物生育阻害因子である。アルミニウムイオン毒 性の特徵は速やかな根の伸長阻害であるが、その毒性メカニズムについては未だ明らかにされていな い。一方、アルミニウムイオン毒性に対して耐性を示す植物が一部存在する。その耐性機構について 様々な仮説が提唱されているが、我々はアルミニウムの存在形態によって毒性が異なるという点に着 目して、根からのアルミニウムキレート物質の分泌を耐性機構の一つとして考え、耐性植物の根分泌 液中のアルミニウムキレート物質の検索を行ってきた。その結果、幾つかの植物の根分泌液からアル ミニウムキレート物質が検出された。ここでは、その代表例としてクエン酸とシュウ酸について紹介 する。

\section{1）クエン酸の分泌}

Cassia tora L.（和名 エビスグサ）はマメ科植物でアルミニウム毒性に比較的強い耐性をもって いる（鬼頭、服部、1996）。この植物にアルミニウム処理すると、根からクエン酸と同定される物質 が分泌された(Ma et al., 1997a)。図3に示すように、根の中に数種類の有機酸が存在しているが、ア ルミニウムの処理によってクエン酸のみが選択的に分泌された。これはクエン酸がアルミニウムと強 く錯体を作り、アルミニウムイオンを無毒化することが出来るからである。アルミニウムによるクエ ン酸の分泌過程は図4に示すように、アルミニウム処理後 4 時間まではクエン酸の分泌はほとんど認 められなかったが、その後、顕著に増加した。このアルミニウム処理とクエン酸の分泌との間の時間 的ずれは何らかの誘導過程が含まれている可能性を示唆している。またクエン酸の分泌はアルミニウ ムに対する特異性を示し、他のイオン（例えば、La、Yb）やリン酸欠乏では分泌が起こらない。ア ルミニウムを除去すると、翌日クエン酸の分泌が停止するが、アルミニウムを添加すると、再びクエ ン酸の分泌が起こる。さらに、クエン酸の分泌量はアルミニウム処理濃度の増加に伴って、増加した。 
これらの結果はエビスグサの根が特異的にアルミニ ウムキレート物賓であるクエン酸を分必し、根圈に おいてアルミニウムを無毒化する機構を持っている ことを示している。今後、さらにクエン酸合成関連 酵素の活性変動やアニオンチャンネルの活性化など について調ベクエン酸分泌の誘導過程を解析してい く必要がある。

2）シュウ酸の分泌

ソバは強いアルミニウム耐性を示す植物として知 られている。中国南部酸性土壤地域によく生育して いるソバ（品種 Jianxi）の根にアルミニウム処理 すると、シュウ酸と同定される物貿が分泌されてい ることが明らかとなった(Ma et al., 1997b, Zheng et al., 1998).。シュウ酸は一番簡単なジカルボン酸 であるが、アルミニウムとの間に三種類の錯体(1:1， 1:2，1:3)を作ることができる。特に1:3(Al:シュウ 酸)錯体は根の伸長にとって無毒の形態である（図 1）。アルミニウムによるシュウ酸の分泌はアルミ ニウム処理後30分のうちに起こり、時間の経過とと もに分泌量が直線的に増加した（図4）。アルミニ ウム添加後シュウ酸が速やかに分泌されるのはエビ スグサの場合と違った応答反応である（図4）。ま たシュウ酸の分泌量はアルミニウム処理濃度の増加 につれ増加した。根におけるシュウ酸の分泌部位を 調べたところ、根の先端から $1 \mathrm{~cm}$ までのところに限 られていた。さらにC. toraと同様、シュウ酸の分 泌はリン酸欠乏やランタンによって誘導されず、ア ルミニウムによる特異的な応答反応を示す。



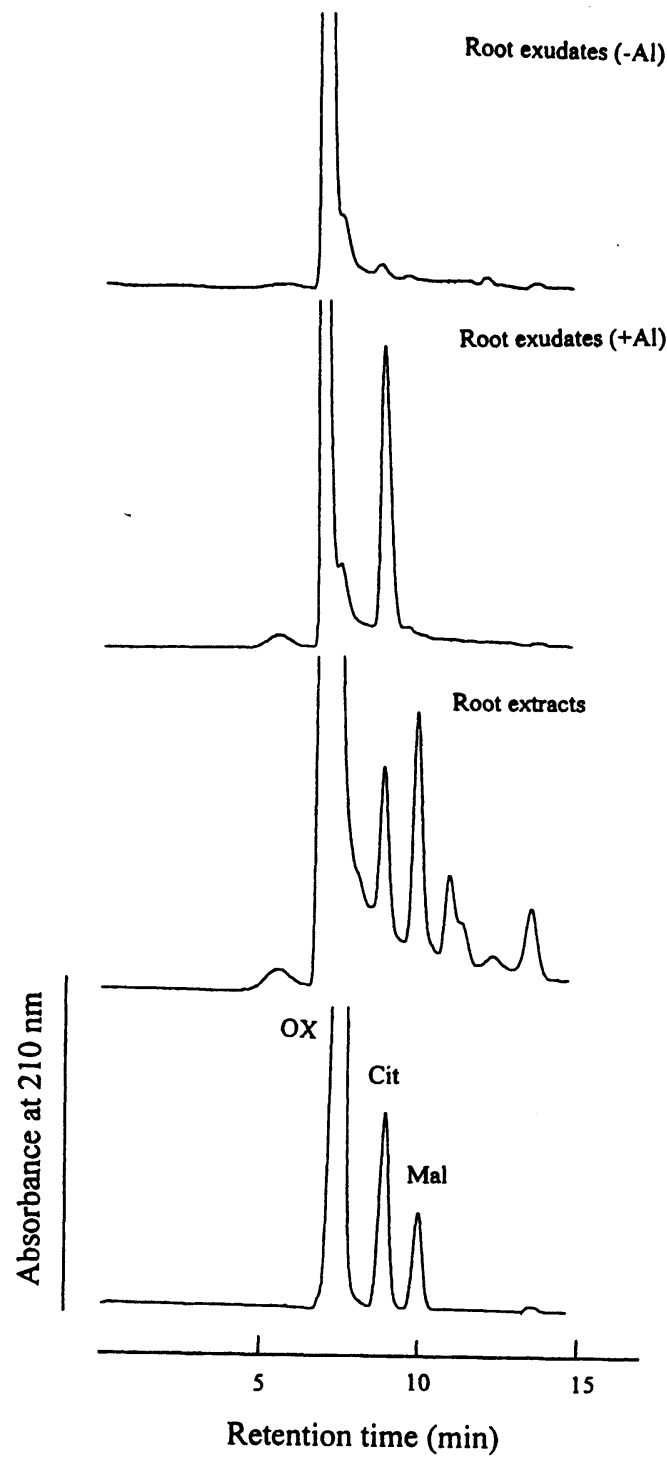

図3 根分泌液及び抽出液のHPLCプロフィール

b



Time after Al treatment (hr)

図4 アルミニウムによるクエン酸(a)とシュウ酸(b)分必の経時変化 (Ma et al., 1997a, b) 
シュウ酸はカルシウムと結合して、不溶性のシュウ酸カルシウムを形成することがよく知られてい る。しかし、シュウ酸はカルシウムよりもアルミニウムとの結合能力の方がはるかに強いため、アル ミニウムによるシュウ酸の分泌がカルシウムの栄養不足を引き起こすとは考えられない。

クエン酸やシュウ酸以外に、リンゴ酸がアルミニウム耐性のコムギの根から分泌されると報告され ている(Delhaize et al., 1993).有機酸は植物体内で代謝やpHの調節等に関係する大切な成分で、量の 違いはあるものの、ほとんどの植物に存在している。しかし、なぜ一部の耐性植物だけがアルミニウ ムによって有機酸を分泌するのかは、興味深い。またなぜクエン酸あるいはシュウ酸だけが特異的に 分泌されるのかも不思議である。今後さらに分泌に至るまでの機構を検討する必要がある。

3.おわりに

以上述べたように、イネ科植物の根 からは鉄欠乏に応答して、鉄キレート 物質であるムギネ酸類が分泌される。

一方、一部のアルミニウム耐性植物で はアルミニウムイオンによって根から アルミニウムキレート物質クエン酸や シュウ酸が特異的に分泌される。同じ 分泌過程ではあるが、その分泌の仕方 が違うようである。図5は両方の模式 図を示す。ムギネ酸類分泌の場合、不 溶性の鉄を獲得するために、大量に根 外に分泌する必要がある。一方、アル

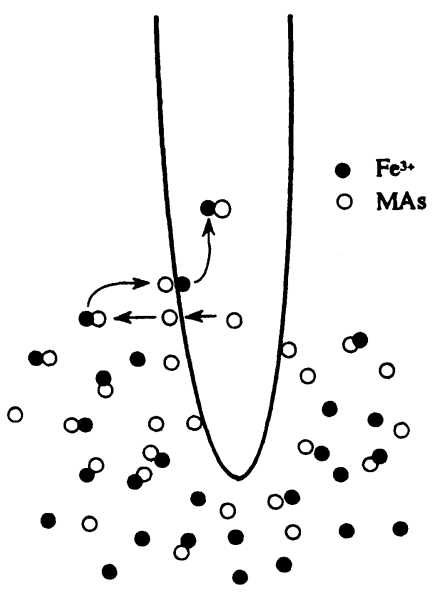

図5 ムギネ酸類の分泌とAlキレート物質の分泌の模式図

ミニウムの毒性は根の先端しか発現しないので、先端の表面近くでクエン酸やシュウ酸の濃度を高く 維持するだけで充分である。この分泌の仕方の違いは植物が必須元素である鉄を獲得するために取っ た戦略と有害元素であるアルミニウムを無毒化するために取った戦略が異なるためと理解される。 引用文献

Delhaize, E. et al. (1993) Plant Physiol. 103: 695-702.

鬼頭誠、服部とも子 (1996) 日本土肥学会関西支部講演会要旨集 42:367.

Kawai, S. et al. (1988) Tetrahedron Lett 29: 1053-1056.

Ma, J. F. and Nomoto, K. (1992) Chem. Pharm. Bull 40: 2888-2890.

Ma, J. F. and Nomoto, K. (1993) Plant Physiol. 102: 373-378.

Ma, J. F. and Nomoto, K. (1994a) Soil Sci. Plant Nutri. 40: 311-317.

Ma, J. F. and Nomoto, K. (1994b) Plant Physiol. 105: 607-610.

Ma, J. F. et al. (1995) J. Biol. Chem. 270: 16549-16554.

Ma, J. F. and Nomoto, K. (1996) Physiol. Plant. 97: 609-617.

Ma, J. F. et al. (1997a) Plant Cell Physiol. 38: 1019-1025.

Ma, J. F. et al (1997b) Nature 390: 569-570.

Ma, J. F. et al. (1998) Planta in press.

Mori, S. and Nishizawa, N. (1987) Plant Cell Physiol 28: 1081-1092.

Römheld, V. (1987) Physiol Plant 70: 231-234.

Zheng, S. J. et al. (1998) Plant Physiol. 117: 745-751.

Takagi, S. et al. (1984) J. Plant Nutri., 7: 469-477.

Takemoto, T. et al. (1978). Proc. Jpn. Acad, 54: B469-473.

Role of metal-chelating substances in root exudates. Jian Feng Ma 